\author{
LIMNOLOGX AND OCEANOGRAPHY \\ Yol. 20, No. 5, Septcmber 1975 Pp.
Made in the United States of America \\ (C) Copyright, 1975, by The American Society of I.imnology and Oceanography, Inc.
}

\title{
Oxygen-nutrient relationships in the Pacific Ocean ${ }^{1}$
}

\author{
Saul Alvarez-Borrego \\ Instituto de Investigaciones Oceanologicas, Universidad Autonoma de Baja California, Ensenada, \\ Mcxico
}

\section{Charles H. Culberson and P. Kilho Park}

Scliool of Oceanography, Oregon State University, Corvallis 97331

\begin{abstract}
In the northcastern Pacific Ocean the oxygen-phosphate and oxygen-nitrate relationships vary systematically with latitude. The variation above the oxygen minimum zone is much more pronounced than below it. The slopes of these relationships in general increase with increasing latitude. In the entire water column these slopes vary with depth. A seasonal effect on the slopes of the oxygen-phosphate and oxygen-nitrate relationships, similar to that with decreasing latitude, is observed; the winter slopes are higher than the summor slopes. Potential temperature versus preformed phosphate diagrams were constructed for different stations in the Pacific and Indian Oceans to study their water masses.
\end{abstract}

Postma (1964) plotted dissolved oxygen concentrations, $O_{2}$, versus phosphate concentrations, $\mathrm{PO}_{\text {. }}$, from stations at different latitudes $\left(55^{\circ} \mathrm{N}\right.$ to $\left.62^{\circ} \mathrm{S}\right)$ in the Pacific Ocean, and found a variable $\Delta \mathrm{O}_{2}: \Delta \mathrm{PO}_{4}$ ratio with depth. Pytkowicz (1964) and Park (1967a) found a linear relationship of $\mathrm{O}_{2}$, versus $\mathrm{PO}_{4}$ above the oxygen minimum zone off the Oregon coast. AlvarezBorrego et al. $(1972,1975)$ tested Redfield's model for $\mathrm{O}_{2}$-nutrient relationships and found it consistent with the field data, showing that the variation of the $\mathrm{O}$-nutrient relationship slopes with depth, latitude, and time of the year is due to mixing between different water types with different preformed portions of $\mathrm{O}_{2}$ and nutrients. Diagrams of $\mathrm{O}_{2}$ versus nutrient may thus be used to characterize water masses and preformed nutrient (Redfield 1942) versus temperature diagrams may be used to detect and trace water masses that are not very well identified by $T-S$ diagrams.

The purpose of this work is to study the

\footnotetext{
${ }^{1}$ This work was supported by National Science Foundation grants GX-38167 and GA-12113 and Office of Naval Research contract N00014-67- $\Lambda$ 0369-0007 under project NR-083-102. The "Consejo Nacional de Ciencia y Tecnologia" of Mexico supported the work of $S$. Alvarez-Borrego. This paper comprises part of a dissertation submitted by $\mathrm{S}$. Alvarez-Borrego in partial fulfillment of the requirements for the Ph.D. at Oregon State University.
}

$\mathrm{O} .-\mathrm{PO}_{4}$ and $\mathrm{O}-\mathrm{NO}_{3}$ relationships for the northeastern Pacific Ocean and sontheastcrn Bering Sea, and to trace Pacific Intermediate Waters using preformed nutrient versus potential temperature, $\theta$, diagrams.

\section{Sources of data}

We used salinity, temperature, oxygen, phosphate, and nitrate data from stations 3801 and 3804 of cruise 26 of Vityaz, November 1957, in the Central Pacific Ocean (obtainable from National Oceanographic: Data Center); from several stations of $R V$ Anton Bruun cruise 2, May-July 1964, in the Indian Ocenn (Woods Hole Ocennogr. Inst. Final Cruise Rep. Anton Bruun Cruise 2) from station 116 of the BOREAS expedition, winter 1966 (Scripps Inst. Oceanogr. Data Rep. Ref. 66-2A) in the subarctic Pacific region; from several stations of YALOC-66 summer 1966 (Barstow et al. 1968) from Iawaii to Adak, Alaska, and the southeastem Bering Sea; from several stations of the SCORPIO expedition, May 1967 (Scripps Inst. Oceanogr. Data Rep. Ref. 69-15, Woods Hole Oceanogr. Inst. Data Rep. Ref. 69-56) in the South Pacific Ocean; and from station GOGO-1 of a GEOSECS intercalibration and test cruise, November 1971 (unpublished chemical occanographic data, Oregon State Univ.) off California. The positions of these stations are shown in Fig. 1. 


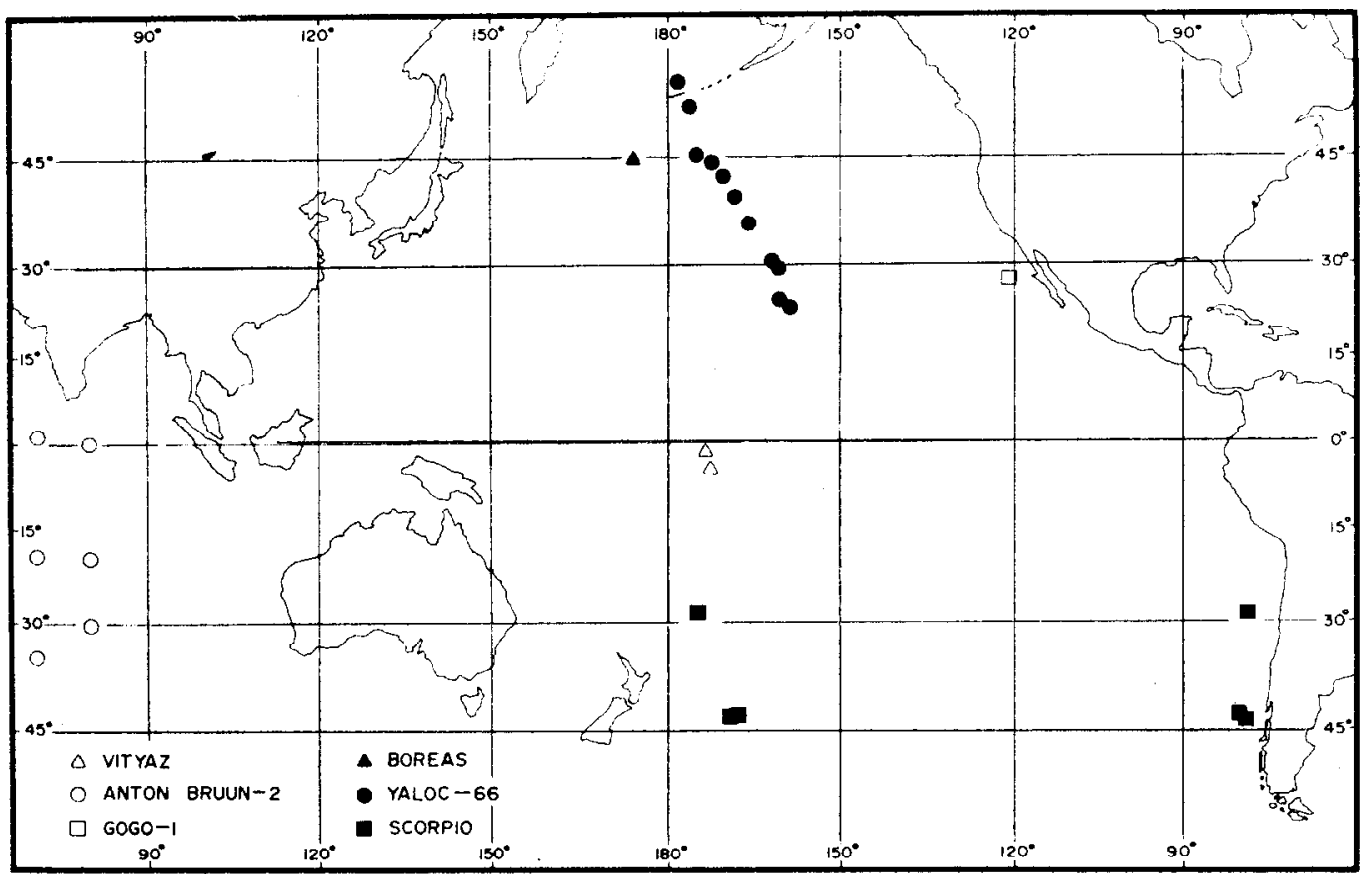

Fig. 1. Locations of the stations used in this study.

\section{Results}

In the northeastern Pacific Ocean the $\mathrm{O}_{2}-\mathrm{PO}_{4}$ and $\mathrm{O}_{2}-\mathrm{NO}_{3}$ relationships for the region of the water column above and below the $\mathrm{O}_{2}$ minimum zone vary systematically with latitude (Figs. 2 and 3 ). The variation above the $\mathrm{O}_{2}$ minimum zone is much more pronounced than below it. The slopes of these relationships in general increase with increasing latitude; in the entire water column, they vary with depth. The slopes are steeper in winter than in summer (Figs. 4 and 5 ).

These variations of the $\mathrm{O}_{2}-\mathrm{PO}_{4}$ and $\mathrm{O}_{2}-$ $\mathrm{NO}_{3}$ slopes were estimated by applying the least squares method to the $\mathrm{O}_{2}, \mathrm{PO}_{4}$, and $\mathrm{NO}_{3}$ field data. The confidence intervals were estimated at the $95 \%$ confidence level. $\mathrm{O}_{2}$ is expressed in $\mathrm{ml}$ liter ${ }^{-1}$ and $\mathrm{PO}_{4}$ and $\mathrm{NO}_{3}$ in $\mu \mathrm{M}$. Above the $\mathrm{O}_{2 .}$ minimum zone the slope of the $\mathrm{O}_{2}-\mathrm{PO}_{4}$ diagram varies from $-1.40 \pm 0.20$ near Hawaii to $-5.26 \pm$ 0.70 in the southeastern Bering Sea (Fig. 2 ). The slope of the $\mathrm{O}_{2}-\mathrm{NO}_{3}$ diagram varies from $-0.085 \pm 0.014$ near Hawaii to $-0.278 \pm 0.060$ in the southeastern Bering

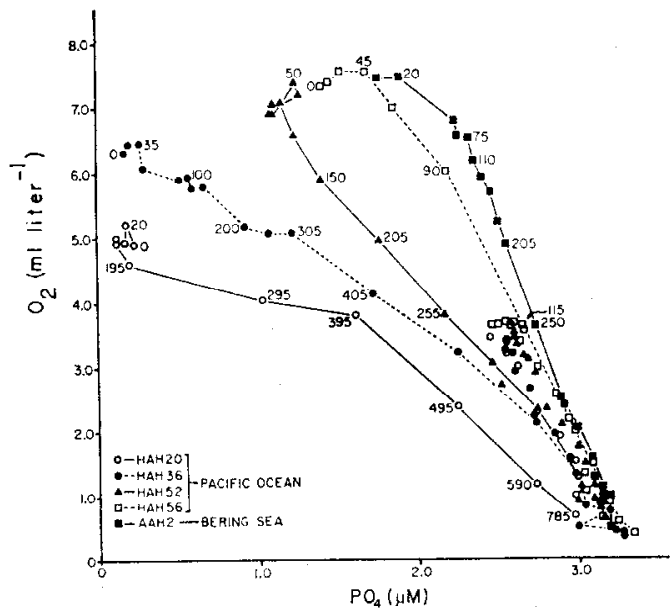

Fig. 2. Oxygen-phosphate diagram. The numbers by the data points represent depth in meters. The lines are joining the data points above the oxygen minimum zone. The positions of the stations are: $\mathrm{HAH} 20\left(22^{\circ} 53.8^{\prime} \mathrm{N}, 158^{\circ} 54.7^{\prime} \mathrm{W}\right)$, HAII36 $\left(38^{\circ} 53.3^{\prime} \mathrm{N}, 168^{\circ} 13.6^{\prime} \mathrm{W}\right)$, HAH52 $\left(45^{\circ}\right.$ $\left.52.8^{\prime} \mathrm{N}, 174^{\circ} 02.3^{\prime} \mathrm{W}\right)$, HAH56 $\left(50^{\circ} 27.5^{\circ} \mathrm{N}, 176^{\circ}\right.$ $\left.13.8^{\prime} \mathrm{W}\right)$, AAH2 (52 $\left.56.1^{\prime} \mathrm{N}, 177^{\circ} 55.0^{\prime} \mathrm{W}\right)$. 


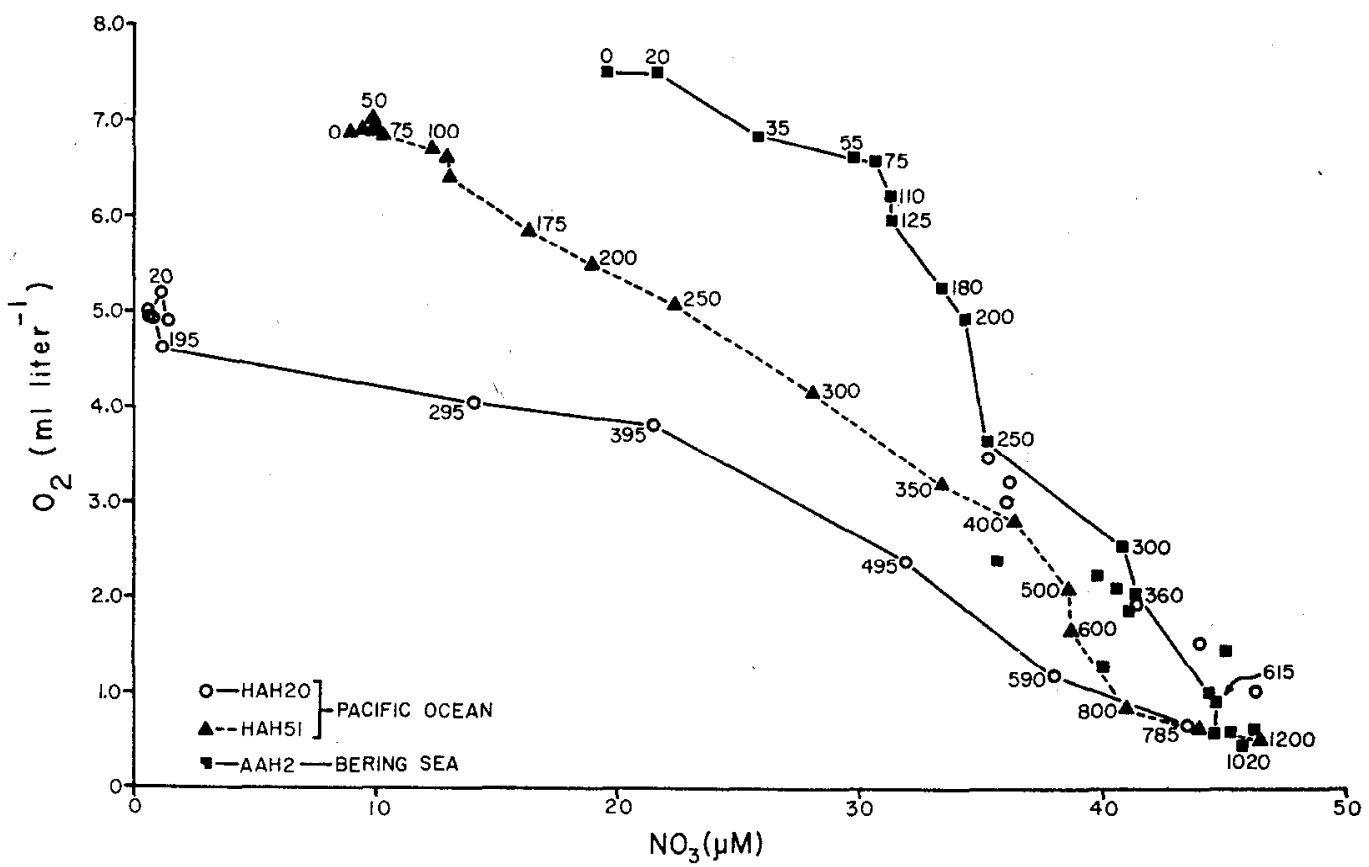

Fig. 3. Oxygen-nitrate diagram. Data presented as in Fig. 2. The position of the station not given in the legend to Fig. 2 is: HAH51 $\left(44^{\circ} 17.0 \mathrm{~N}, 173^{\circ} 06.3^{\prime} \mathrm{W}\right)$.

Sea (Fig. 3). Below the $\mathrm{O}_{2}$ minimum zone the $\mathrm{O}_{2}-\mathrm{PO}_{4}$ slope varies from $-4.24 \pm 0.70$ near Hawaii to $-6.01 \pm 0.50$ in the southeastern Bering Sea; the $\mathrm{O}_{2}-\mathrm{NO}_{3}$ slope varies from $-0.169 \pm 0.012$ near $28^{\circ} \mathrm{N}$, off Cali-

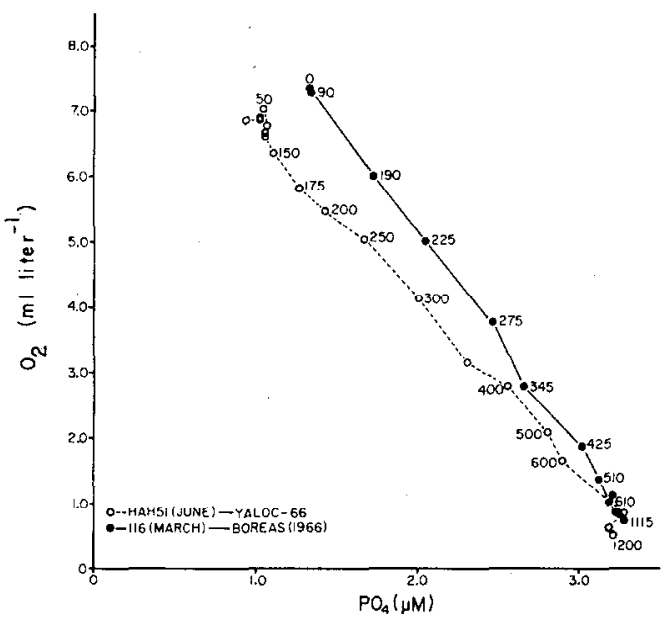

Fig. 4. Oxygen-phosphate diagram. Comparison between winter and summer data. The numbers by the data points represent depth in metcrs. The position of the station not given in the legend to Fig. 3 is: $116\left(44^{\circ} 51.0^{\prime} \mathrm{N}, 174^{\circ} 57.0^{\prime} \mathrm{E}\right)$. fornia, to $-0.404 \pm 0.022$ in the southeastern Bering Sea.

Above the $\mathrm{O}_{2}$ minimum zone, near $45^{\circ} \mathrm{N}$, $180^{\circ}$, the $\mathrm{O}_{2}-\mathrm{PO}_{4}$ slope varies from -3.38 \pm 0.08 in March to $-2.74 \pm 0.10$ in June (Fig. 4); the $\mathrm{O}_{2}-\mathrm{NO}_{3}$ slope varies from

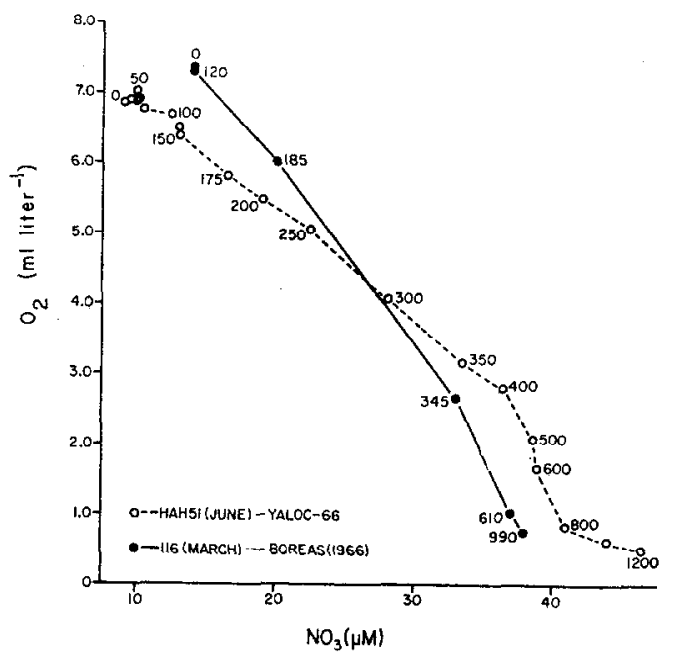

Fig. 5. Oxygen-nitrate diagram. Data presented as in Fig. 4. 
Oxygen-nutrient relationships
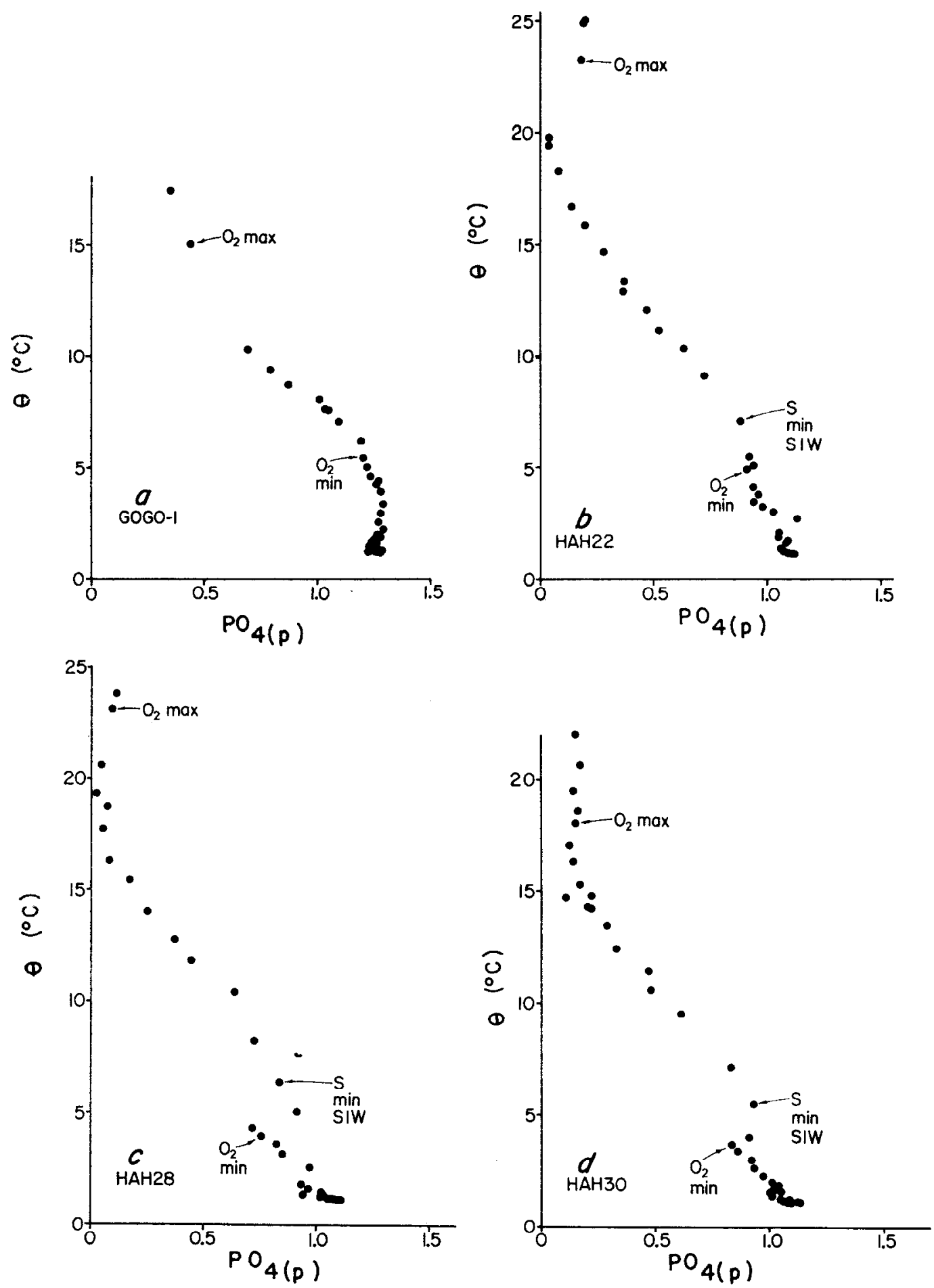

Fig. 6. $\theta$ versus $\mathrm{PO}_{4(\mathrm{p})}$ diagrams. a-GOGO-1 $\left(28^{\circ} 29.0^{\prime} \mathrm{N}, 121^{\circ} 38.0^{\circ} \mathrm{W}\right) ; \mathrm{b}-\mathrm{HAH} 22\left(24^{\circ} 30.6^{\prime} \mathrm{N}\right.$, $\left.161^{\circ} 30.0^{\prime} \mathrm{W}\right) ; \quad c-\mathrm{HAH}_{2} 8\left(29^{\circ} 10.0^{\prime} \mathrm{N}, 161^{\circ} 28.0^{\prime} \mathrm{W}\right) ; \mathrm{d}-\mathrm{HAH} 30\left(30^{\circ} 55.4^{\prime} \mathrm{N}, 162^{\circ} 37.4^{\prime} \mathrm{W}\right)$. SIW means Subarctic Intermediate Water. 

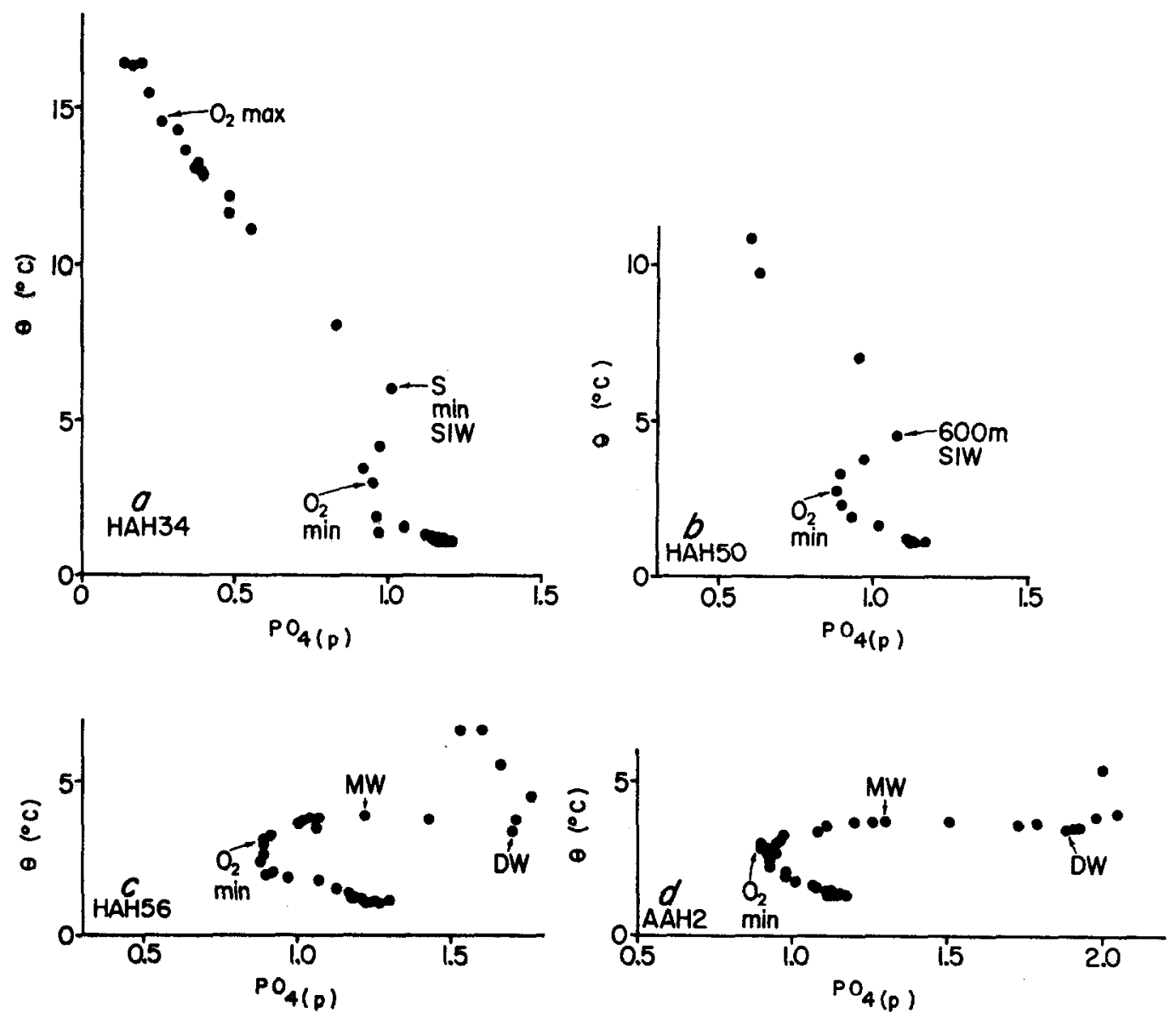

Fig. 7. $\theta$ versus PO(p) diagrams. a-HAH34 $\left(35^{\circ} 26.5^{\prime} \mathrm{N}, 165^{\circ} 47.8^{\prime} \mathrm{W}\right) ; \mathrm{b}-\mathrm{HAH} 50\left(43^{\circ} 04.6^{\prime} \mathrm{N}\right.$, $\left.171^{\circ} 25.0^{\circ} \mathrm{W}\right)$; $c-\mathrm{HAH56}$; d-AAH2. SIW means Subarctic Intermediate Water.

$-0.270 \pm 0.020$ in March to $-0.169 \pm 0.012$ in June (Fig. 5).

\section{Discussion}

According to Alvarez-Borrego et al. (1975) the variation of the $\mathrm{O}_{2}$-nutrient slopes, presented above, is due to mixing between different water types with different preformed, conservative portions of $\mathrm{O}_{2}$ and nutrients. A better insight into these mixing processes can be obtained from an analysis of $\theta$-preformed nutrient diagrams. Since Redfield's model was found consistent with field $\mathrm{O}_{2}$ and nutrient data (Alvarez-Borrego et al. 1975), the model can be used to calculate preformed nutrients. Since $\mathrm{PO}_{4}$ data from YALOC-66 cruise are more pre- cise than $\mathrm{NO}_{3}$ data, we use here the calculated preformed phosphate, $\mathrm{PO}_{4(p)}$, to construct $\theta-\mathrm{PO}_{4(\mathrm{n})}$ diagrams. In most cases, both $\theta-\mathrm{PO}_{4(\mathrm{p})}$ and $\theta-\mathrm{NO}_{3(\mathrm{p})}$ diagrams provide the same information. Pytkowicz (1968) used $T-\mathrm{PO}_{4(\mathrm{n})}$ diagrams to characterize water masses in the Southern Ocean.

Figures 6, 7, and 8 show the $\theta-\mathrm{PO}_{4(\mathrm{n})}$ diagrams for different parts of the Pacific Ocean and the southeastern Bering Sea. Figures 6c,d and 7a,b show a $\mathrm{PO}_{4(p)}$ maximum and a deep $\mathrm{PO}_{4(\mathrm{p})}$ minimum. The $\mathrm{PO}_{4(\mathrm{p})}$ maximum indicates the presence of Subarctic Intermediate Water. Park (1967b) used $\mathrm{PO}_{4(p)}$ to characterize Subarctic Intermediate Water in a section constructed with data from leg HAH of YALOC-66. 


\section{Oxygen-nutrient relationships}
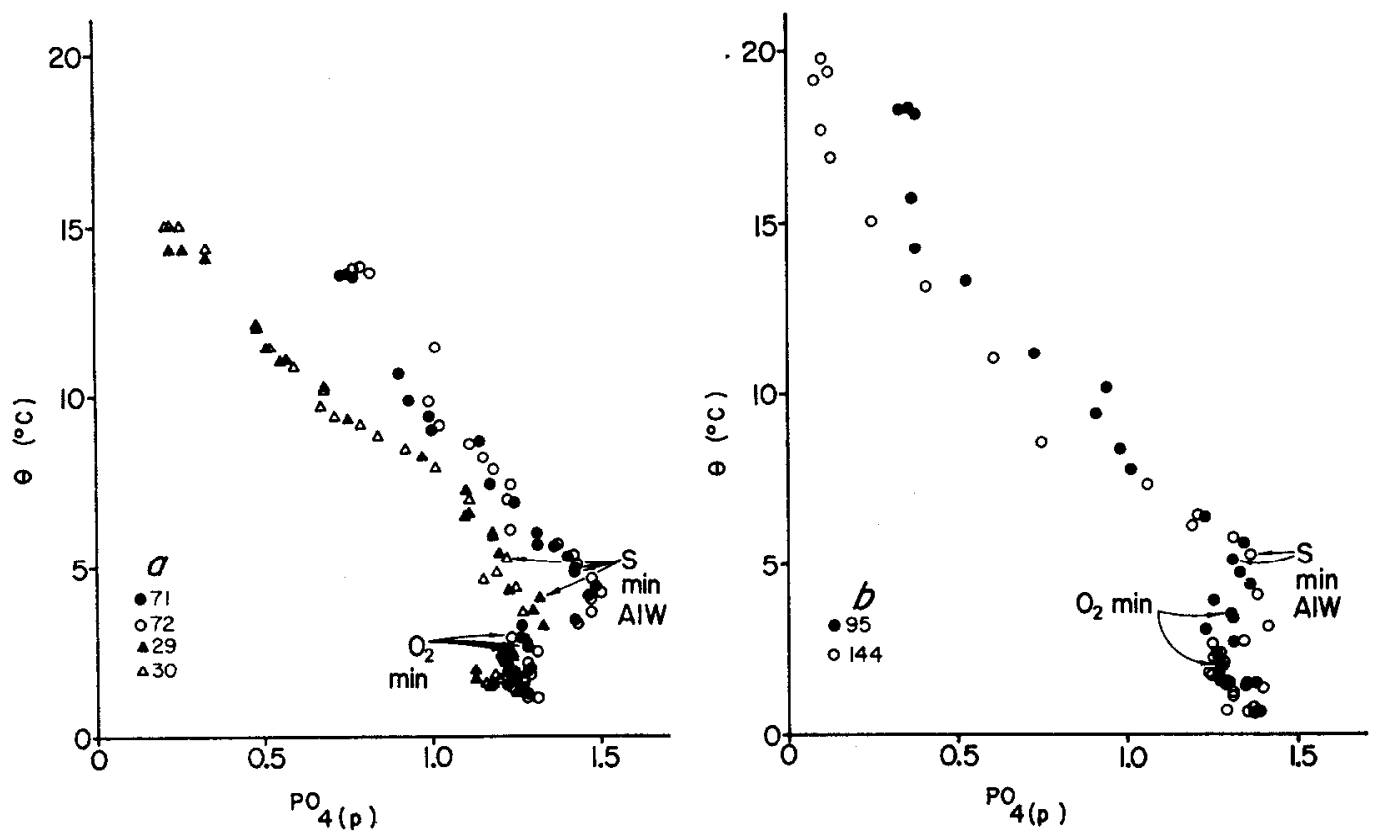

Fig. 8. $\theta$ versus $\mathrm{PO}_{4(\mathrm{p})}$ diagrams. $\mathrm{a}-$ Stations $29,30,71$, and $72 ; \mathrm{b}-95$ and 144 of SCORPIO expedition. Station positions are: $29\left(43^{\circ} 15.0^{\prime} \mathrm{S}, 169^{\circ} 50.0^{\prime} \mathrm{W}\right), 30\left(43^{\circ} 15.0^{\prime} \mathrm{S}, 169^{\circ} 04.5^{\prime} \mathrm{W}\right), 71\left(43^{\circ}\right.$ $\left.14.7^{\prime} \mathrm{S}, 80^{\circ} 02.0^{\prime} \mathrm{W}\right), 72\left(43^{\circ} 19.0^{\prime} \mathrm{S}, 79^{\circ} 01.5^{\prime} \mathrm{W}\right), 95\left(28^{\circ} 15.7^{\prime} \mathrm{S}, 79^{\circ} 07.3^{\prime} \mathrm{W}\right)$, and $144\left(28^{\circ} 15.7^{\prime} \mathrm{S}, 170^{\circ}\right.$ $\left.14.8^{\prime} \mathrm{W}\right)$. AIW means Antarctic Intermediate Water.

The Subarctic Intermediate Water has bccn classically characterized by a salinity, $S$, minimum. According to Reid (1965) this $S$ minimum is recognizable as far south as $10^{\circ} \mathrm{N}$, along $160^{\circ} \mathrm{W}$. Park's (1967b) section also shows the deeper $\mathrm{PO}_{4(\mathfrak{p})}$ minimum. The $\mathrm{PO}_{4(\mathrm{p})}$ minimum (Figs. 6c,d and 7) coincides with the $\mathrm{O}_{2}$ minimum. Alvarez-Borrego et al. (1972) found the $\mathrm{PO}_{4(\mathrm{p})}$ minimum in the southeastern Bering Sea and thought it possibly the core of a water mass which when at the sea surface had undergone intense photosynthesis, with depletion of $\mathrm{PO}_{4}$ to very low values accompanied by equilibration of the dissolved $\mathrm{O}_{2}$ with the atmosphere.

Off Baja California and near Hawaii (stations GOGO-1 and HAH22) (Figs. 1 and $6 \mathrm{a}, \mathrm{b})$ neither the $\mathrm{PO}_{4(\mathrm{y})}$ maximum nor the minimum is apparent. At station HAH30 the $\mathrm{PO}_{4(\mathrm{p})}$ minimum (Fig. 6d) almost coincides with the sigma- $t$ surface of 27.28 that Reid (1965) used to study the Antarctic Intermediate Water. According to Reid this sigma- $t$ surface lies more than
$350 \mathrm{~m}$ below the sea surface everywhere in the North Pacific. If the explanation given by Alvarez-Borrego et al. (1972) for the $\mathrm{PO}_{4(\mathrm{p})}$ minimum is correct, the source of this water should not be in the North Pacific Ocean.

Figure 8 shows that the Antarctic Intermediate Water is not characterized by a $\mathrm{PO}_{4(\mathrm{p})}$ minimum in the South Pacific. Thus, the $\mathrm{PO}_{4(\mathrm{p})}$ minimum present in the North Pacific Ocean and southeastern Bering Sea is not formed at the Pacific sector of the Antarctic Convergence. Figure 8a shows that for stations 71 and 72 (off Chile) of the SCORPIO expedition, the Antarctic mediate Water is not characterized by a well defined $\mathrm{PO}_{4(\mathrm{p})}$ maximum. Redfield (1942) found this $\mathrm{PO}_{4(\mathrm{p})}$ maximum from the Antarctic Convergence to about $10^{\circ} \mathrm{N}$ in the Atlantic Ocean. For stations 29 and 30 of the SCORPIO expedition (off New Zealand) the $\mathrm{PO}_{4(\mathrm{p})}$ maximum is not apparent. These four stations are at the same latitude (Fig. 1). Although Fig. Sa does not show the $\theta-\mathrm{PO}_{4(1)}$ diagrams for stations 

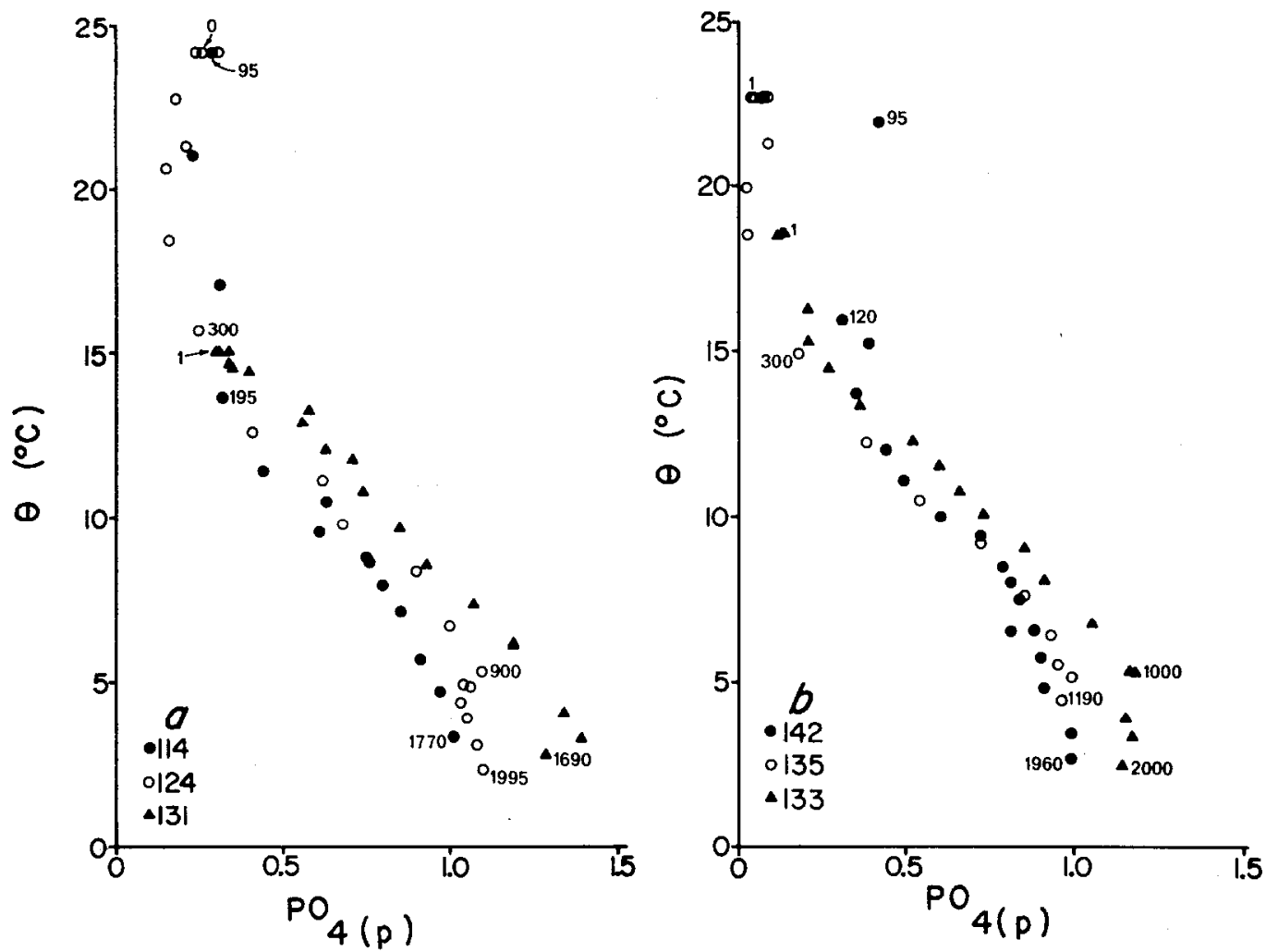

Fig. 9. $\theta$ versus $\mathrm{PO}_{4(\mathrm{p})}$ diagrams, a-Stations 114,124 , and $131 ; \mathrm{b}-133,135$, and 142 of Anton Bruun cruise 2. Station positions are: $114\left(01^{\circ} 00^{\prime} \mathrm{N}, 70^{\circ} 01^{\prime} \mathrm{E}\right), 124\left(19^{\circ} 30^{\prime} \mathrm{S}, 69^{\circ} 51^{\prime} \mathrm{E}\right), 131\left(35^{\circ} 09^{\prime} \mathrm{S}\right.$, $\left.69^{\circ} 59^{\prime} \mathrm{E}\right), 133\left(30^{\circ} 11^{\prime} \mathrm{S}, 79^{\circ} 42^{\prime} \mathrm{E}\right), 135\left(20^{\circ} 02^{\prime} \mathrm{S}, 79^{\circ} 50^{\prime} \mathrm{E}\right)$, and $142\left(00^{\circ} 33^{\prime} \mathrm{S}, 80^{\circ} 08^{\prime} \mathrm{E}\right)$.

located between 30 and 71 and between New Zealand and the southern Australian coast, the $\mathrm{PO}_{4(\mathrm{p})}$ maximum diminishes gradually from east to west at this latitude in the South Pacific. Station 71 has almost the same geographic location as 72 , and station 29 has almost the same geographic location as 30 . We have plotted the $\theta$ $\mathrm{PO}_{4(p)}$ diagrams for 71,72 and 29,30 to check for consistency of the data.

If the $\mathrm{PO}_{4(\mathrm{p})}$ minimum found in the North Pacific Ocean is not formed at the Antarctic Convergence, the only possibility left is that it is formed in the eastern Atlantic Ocean and western Indian Ocean sectors. It may be transported through the Indian Ocean and the Celebes Sea, north of Australia, into the Pacific Ocean. This is a very remote possibility indeed, but to include it, we plotted $\theta-\mathrm{PO}_{4(\mathrm{p})}$ diagrams for several stations of Anton Bruun cruise
2. Figure 9 shows that there is no $\mathrm{PO}_{4(p)}$ minimum or maximum in the Indian Ocean between $35^{\circ} \mathrm{S}$ and $00^{\circ}$; The values of deep waters decrease northward, possibly because of mixing with surface water with low $\mathrm{PO}_{4(p)}$. Thus, the $\mathrm{PO}_{1(\mathrm{p})}$ minimum at intermediate depths in the North Pacific Ocean and southeastern Bering Sea is not formcd at any sea surface source.

Figure 10 shows $\theta-\mathrm{PO}_{4(\mathrm{p})}$ diagrams for two stations of cruise 26 of Vityaz in the Central Pacific Ocean (near the equator). Unfortunately there are only a few data points for these two stations, and the near surface data points with $\theta>20^{\circ} \mathrm{C}$ are not plotted. Nevertheless, no significant minimum or maximum is shown below a few hundred meters depth. At this location the Antarctic Intermediate Water has lower values of $\mathrm{PO}_{4(\mathrm{p})}$ than the deeper waters and higher values than the shallower waters. 

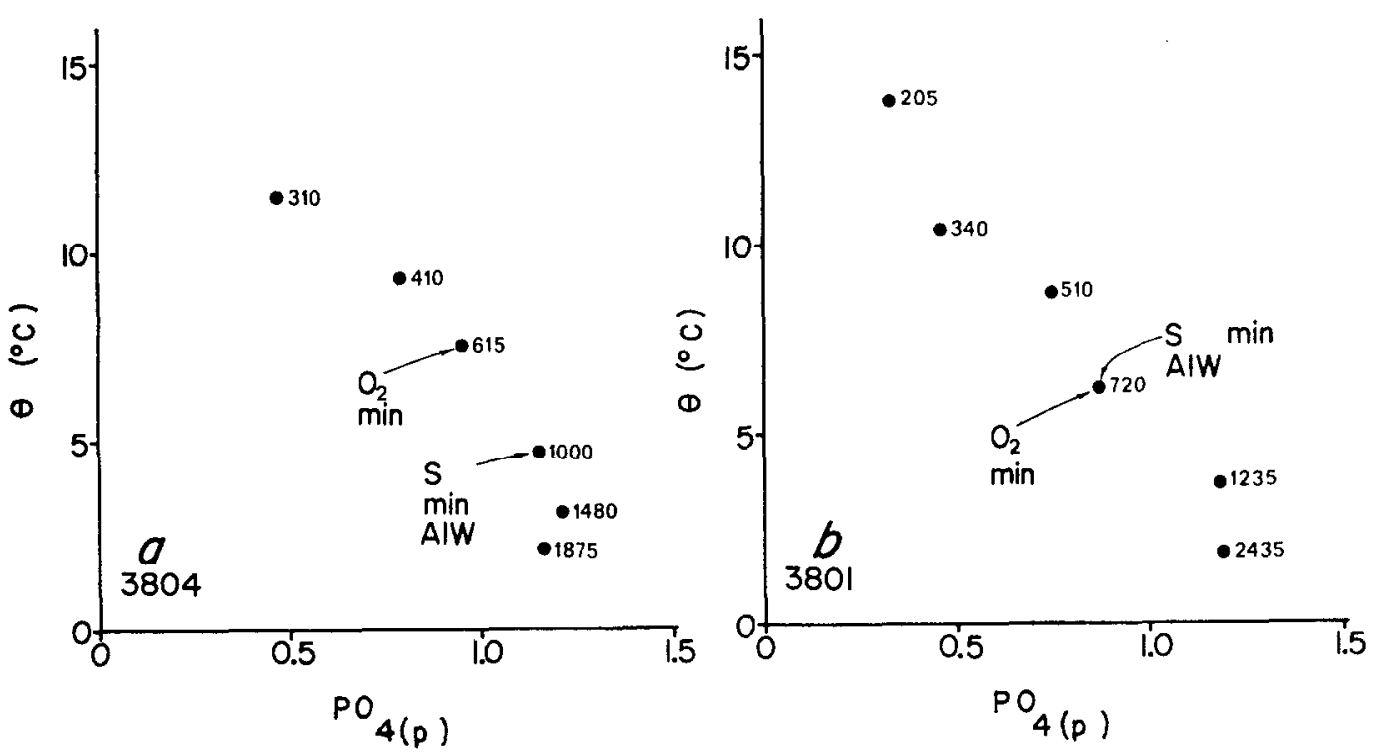

Fig. 10. $\theta$ versus $\mathrm{PO}_{4(\mathrm{p})}$ diagrams. a-Station $3804 ; \mathrm{b}-3801$ of expedition 26 of the Vityaz. The numbers by the data points represent depth in meters. Station positions are: $3804\left(04^{\circ} 57^{\prime} \mathrm{S}, 172^{\circ}\right.$ $\left.36^{\prime} \mathrm{W}\right)$ and $3801\left(02^{\circ} 25^{\prime} \mathrm{S}, 173^{\circ} 27^{\prime} \mathrm{W}\right)$. AIW means Antarctic Intermediate Water.

Figure 11a illustrates diagrammatically how the $\mathrm{PO}_{4(\mathrm{p})}$ maximum characterizing the Antarctic Intermediate Water in the South Pacific is eroded as it moves northward by mixing with shallower waters with lower $\mathrm{PO}_{4(\mathrm{p})}$ values. The higher $\mathrm{PO}_{4(\mathrm{p})}$ values of the Subarctic Intermediate Water and of the surface waters of the subarctic region cause the $\mathrm{PO}_{4(p)}$ values at intermediate depths to be minimum. Thus, the $\mathrm{PO}_{4(\mathrm{p})}$ minimum observed at high latitudes in the North Pacific is the result of high $\mathrm{PO}_{4(\mathrm{p})}$ valucs in the surface waters of this region of the ocean.

There is a trend for sigma- $t$ values corresponding to the $\mathrm{PO}_{4(\mathrm{n})}$ minimum to increase as latitude increases. At HAH28 the $\mathrm{PO}_{4(\mathrm{p})}$ minimum is at the 27.11 sigma-t surface while at HAH50 it is at 27.44. North of HAH50 (Fig. 1) the sigma- $t$ values corresponding to the $\mathrm{PO}_{4(\mathrm{p})}$ minimum do not change significantly.

The $\mathrm{PO}_{4(p)}$ values for near bottom waters of the stations studied (Figs. 6, 7, 8) differ in some cases from station to station, and from cruise to cruise, by as much as $0.2 \mu \mathrm{M}$. This is probably because there is not yet an international standard for $\mathrm{PO}_{4}$ analyses. Standards are often prepared manually for each station. However, the main problem with $\mathrm{PO}_{4}$ analysis is not accuracy but precision. Steps should be taken to improve the precision of the methods before an international standard is accepted. The data from GEOSECS GOGO-1 are the most precise used here.

\section{Summary}

In the northeastern Pacific Ocean the $\mathrm{O}_{2}-\mathrm{PO}_{4}$ and $\mathrm{O}_{2}-\mathrm{NO}_{3}$ relationships for the region of the water column above and bclow the $\mathrm{O}$. minimum zone vary systematically with latitude. The variation above the $\mathrm{O}_{2}$ minimum zone is much more pronounced than below it. The slopes of these relationships in general increase with increasing latitude. In the entire water column these slopes vary with depth. An effect on the slopes of the $\mathrm{O}_{2}-\mathrm{PO}_{+}$and $\mathrm{O}_{2-}$ $\mathrm{NO}_{3}$ relationships, similar to that observed with decreasing latitude, is seen in comparing seasonal data: winter slopes are steeper.

In the North Pacific Ocean the Subarctic Intermediate Water is characterized by a $\mathrm{PO}_{4(1)}$ maximum. A deeper $\mathrm{PO}_{4(1)}$ mini- 

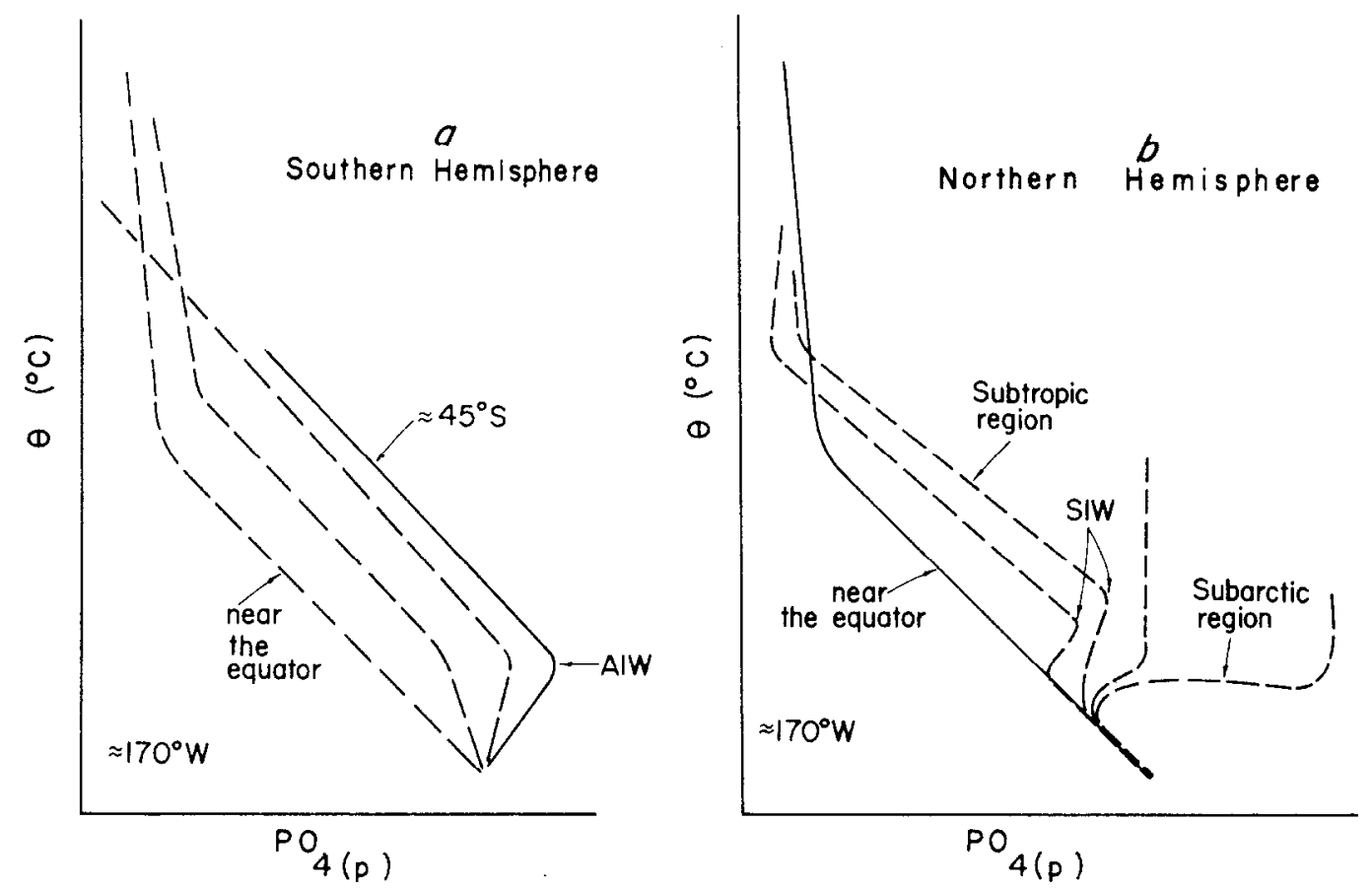

Fig. 11. $\theta$ versus $\mathrm{PO}_{4(\mathrm{p})}$ diagrams. a-South Pacific Ocean; b-North Pacific Ocean. AIW and SIW mean Antarctic Intermediate Water and Subarctic Intermediate Water.

mum is also present. In the South Pacific the Antarctic Intermediate Water is characterized by a $\mathrm{PO}_{4,1}$, maximum that is eroded by mixing with surface water with low $\mathrm{PO}_{4(\mathrm{p})}$ values as the water moves northward. Near the equator, in the Pacific Ocean, there is no minizaum or maximum in the $\theta-\mathrm{PO}_{4(\mathrm{p})}$ diagram. Likewise, in the Indian Ocean there is no minimum or maximum in the $\theta-\mathrm{PO}_{4(\mathrm{r})}$ diagram. The $\mathrm{PO}_{4(11)}$ minimum present at intermediate depths in the northern North Pacific Ocean and Bering Sea results from high $\mathrm{PO}_{4(p)}$ surface values in this oceanic region.

\section{References}

Alvarez-Borrego, S., L. I. Gordov, L. B. Jones, P. K. Pakk, ANu R. M. Prtkowicz. 1972. Oxygen-carbon dioxide-nutrients relationships in the southeastern region of the Bering Sea. J. Oceanogr. Soc. Jap. 28: 71-93.

, D. Guthrie, C. H. Culberson, and P. K. РАнк. 1975. Test of Redfield's model for oxygen-nutrient relationships using regression analysis. Limnol. Oceanogr. 20: 795805 .
Banstow, D., W. Gilbert, K. Park, R. Still, and B. WYATT. 1968. Hydrographic data from Oregon waters, 1966. Oregon State Univ. Dep. Oceanogr. Data Rep. 33. 109 p.

PАнк, K. 1967a. Nutrient regencration and preformed nutrients off Oregon. Limnol. Oceanogr. 12: 353-357.

-1967b. Chemical features of the Subarctic Boundary near $170^{\circ} \mathrm{W}$. J. Fish. Res. Bd. Can. 24: 899-908.

Postra, H. 1964. The exchange of oxygen and carbon dioxide between the ocean and the atmosphere. Neth. J. Sca Res. 2(2): 258-283.

Prokowicz, R. M. 1964. Oxygen exchange rates off the Oregon coast. Dccp-Sca Res. 11: $381-389$.

ㄴ. 1968. Water masses and their properties at $160^{\circ} \mathrm{W}$ in the Southem Ocean. J. Oceanogr. Soc. Jap. 24: 21-31.

Redfield, A. C. 1942. The processes determining the concentration of oxygen, phosphate and other organic derivatives within the depths of the Atlantic Ocean. Pap. Phys. Oceanogr. Meteorol. 9(2): $22 \mathrm{p}$.

REII, L. J. 1965. Intermediate waters of the Pacific Occan. Johns Hopkins.

Submitted: 18 August 1972 Accepted: 8 May 1975 